\title{
T-Cell Surface Glycoprotein CD3 Delta
} Chain

National Cancer Institute

\section{Source}

National Cancer Institute. T-Cell Surface Glycoprotein CD3 Delta Chain. NCI Thesaurus.

Code C38899.

T-cell surface glycoprotein CD3 delta chain (171 aa, $19 \mathrm{kDa}$ ) is encoded by the human CD3D gene. This protein is involved in T-cell-mediated immunity. 